\title{
Y-Doped ZnO Nanorods by Hydrothermal Method and Their Acetone Gas Sensitivity
}

\author{
Peng Yu, ${ }^{1}$ Jing Wang, ${ }^{1}$ Hai-ying Du, ${ }^{1,2}$ Peng-jun Yao, ${ }^{1,3}$ Yuwen Hao, ${ }^{1}$ and Xiao-gan Li ${ }^{1}$ \\ ${ }^{1}$ School of Electronic Science and Technology, Dalian University of Technology, Dalian, Liaoning 116023, China \\ ${ }^{2}$ Department of Electromechanical Engineering and Information, Dalian Nationalities University, \\ Dalian, Liaoning 116600, China \\ ${ }^{3}$ School of Educational Technology, Shenyang Normal University, Shenyang, Liaoning 110000, China
}

Correspondence should be addressed to Jing Wang; wangjing@dlut.edu.cn

Received 21 October 2013; Accepted 9 December 2013

Academic Editor: Xiangyu Zhao

Copyright (C) 2013 Peng Yu et al. This is an open access article distributed under the Creative Commons Attribution License, which permits unrestricted use, distribution, and reproduction in any medium, provided the original work is properly cited.

Pure and yttrium- (Y-) doped (1 at\%, 3 at\%, and 7 at\%) $\mathrm{ZnO}$ nanorods were synthesized using a hydrothermal process. The crystallography and microstructure of the synthesized samples were characterized by X-ray diffraction (XRD), scanning electron microscopy (SEM), and energy dispersive X-ray spectroscopy (EDX). Comparing with pure ZnO nanorods, Y-doped ZnO exhibited improved acetone sensing properties. The response of $1 \mathrm{at} \% \mathrm{Y}$-doped $\mathrm{ZnO}$ nanorods to $100 \mathrm{ppm}$ acetone is larger than that of pure $\mathrm{ZnO}$ nanorods. The response and recovery times of 1 at\% Y-doped $\mathrm{ZnO}$ nanorods to $100 \mathrm{ppm}$ acetone are about $30 \mathrm{~s}$ and $90 \mathrm{~s}$, respectively. The gas sensor based on Y-doped $\mathrm{ZnO}$ nanorods showed good selectivity to acetone in the interfere gases of ammonia, benzene, formaldehyde, toluene, and methanol. The formation mechanism of the $\mathrm{ZnO}$ nanorods was briefly analyzed.

\section{Introduction}

As an important II-VI semiconducting material with a wide direct band gap $\left(E_{g}=3.37 \mathrm{eV}\right.$ at $\left.300 \mathrm{~K}\right)$ and large exciton binding energy $(\sim 60 \mathrm{meV}), \mathrm{ZnO}$ has drawn much attention in the last few decades, owing to its specific electrical, catalytic, photochemical optoelectronic properties and the sensitivity to various gases, all of which make $\mathrm{ZnO}$ highly promising in a broad range of real-world applications $[1,2]$. Recently, $\mathrm{ZnO}$ has shown great potentials for sensing toxic and combustible gases such as $\mathrm{CO}, \mathrm{H}_{2}, \mathrm{NH}_{3}$, ethanol, and acetone [3-5].

One way to enhance gas sensing property is by doping with other elements. For example, Niu et al. [6] used Fe, $\mathrm{Co}$, and $\mathrm{Cr}$ as dopants to improve the gas sensing property of pure $\mathrm{ZnO}$, and the results showed that $\mathrm{ZnFe}_{2} \mathrm{O}_{4}$ had high response and good selectivity to $\mathrm{Cl}_{2}$. Au-doped $\mathrm{ZnO}$ enhanced acetone sensing performance [7]. Co-doped $\mathrm{ZnO}$ nanofibers improved selective acetone sensing properties [8]. $\mathrm{Pd}$ [9] is also used as dopant to improve CO gas sensing property of $\mathrm{ZnO}$. There are some reports about the lanthanide elements of Y-doped $\mathrm{ZnO}$ and $\mathrm{Y}$ doping has significant effects on the luminescence, chemical, and surface modification of
$\mathrm{ZnO}[10,11]$. However, the lanthanide elements of $\mathrm{Y}$ as a dopant to improve gas sensing property of $\mathrm{ZnO}$ are new challenges. Furthermore, many synthesis methods have been used to prepare zinc-oxide nanoparticles (NPs) including chemical vapor deposition [12], sol-gel method [13], spray pyrolysis method [14], solid state reaction method [15], and hydrothermal method [16]. Hydrothermal method is fairly simple and suitable for industrial production, which will pave the way for the development of a low-cost practical gas sensor for detection of probable chemical agents.

In this paper, we report the synthesis and gas sensing properties of pure and $\mathrm{Y}$-doped $\mathrm{ZnO}$ rods using a facile hydrothermal method. One at\% Y-doped $\mathrm{ZnO}$ sensor exhibits improved acetone sensing properties. A possible explanation of sensing mechanism and the effects of Y doping on acetone sensing properties has been analyzed.

\section{Experiments}

2.1. Synthesis and Characterization of $\mathrm{ZnO}$ Nanorods. All the starting materials were analytical grade and were 
used without further purification. Zinc nitrate hexahydrate $\left(\mathrm{Zn}\left(\mathrm{NO}_{3}\right)_{2} \cdot 6 \mathrm{H}_{2} \mathrm{O}\right)$ and yttrium nitrate hexahydrate $\left(\mathrm{Y}\left(\mathrm{NO}_{3}\right)_{3} \cdot 6 \mathrm{H}_{2} \mathrm{O}\right)$ were used as $\mathrm{Zn}$ and $\mathrm{Y}$ sources, respectively. The precipitate reagent was hexamethylene tetramine. $\mathrm{ZnO}$ seed layer was needed before the pure and Y-doped $\mathrm{ZnO}$ samples synthesis. In a typical procedure of seed layer preparation, $21.9 \mathrm{mg}$ zinc acetate $\left(\mathrm{Zn}\left(\mathrm{CH}_{3} \mathrm{COO}\right)_{2} \cdot 2 \mathrm{H}_{2} \mathrm{O}\right)$ was dissolved in $50 \mathrm{~mL}$ deionized water to form a solution with concentration of $2 \mathrm{mM}$. And then the solution was ultrasonically agitated for $0.5 \mathrm{~h}$ to obtain a uniform and transparent zinc acetate solution. This solution was coated onto cleaned glass substrates by a spin coater at a rate of $2200 \mathrm{rpm}$ for $30 \mathrm{~s}$. The coated substrates were dried in room temperature and then annealed at $200^{\circ} \mathrm{C}$ for $1 \mathrm{~h}$ in air to yield a layer of $\mathrm{ZnO}$ seed on the substrate. And then the spin coat and anneal process were repeated two times.

In this process, $630 \mathrm{mg}$ of $\mathrm{Zn}\left(\mathrm{NO}_{3}\right)_{2} \cdot 6 \mathrm{H}_{2} \mathrm{O}$ and certain amount of $\mathrm{Y}\left(\mathrm{NO}_{3}\right)_{3} \cdot 6 \mathrm{H}_{2} \mathrm{O}(0,1$ at $\%, 3$ at $\%$, and 7 at $\%)$ were dissolved in $30 \mathrm{~mL}$ deionized water. Subsequently, $297 \mathrm{mg}$ of hexamethylenetetramine (HMTA: $\mathrm{C}_{6} \mathrm{H}_{12} \mathrm{~N}_{4}$ ) was dissolved into $30 \mathrm{~mL}$ deionized water in another beaker under vigorous stirring for $0.5 \mathrm{~h}$. The $\mathrm{pH}$ of growth solution was $\sim 6$. After that, two solutions were mixed together under stirring and then the seeded glass substrates were immersed into the solution. Then the beaker was put into the oven and kept in it for $8 \mathrm{~h}$ at $95^{\circ} \mathrm{C}$. After the beaker was cooled to room temperature naturally, the substrate was removed from the solution and washed with deionized water and absolute ethanol, respectively, four times. The $\mathrm{ZnO}$ rod powders were obtained after the samples were dried in air at $60^{\circ} \mathrm{C}$.

$\mathrm{X}$-ray diffraction (XRD) patterns of the powders were examined in $2 \theta$ region of $20^{\circ}-80^{\circ}$ with $\mathrm{Cu} K \alpha(0.154 \mathrm{~nm})$ radiation on Rigaku, Model D/M AX 2400, Japan. Scanning electron microscopy (SEM) images were examined on a FEI QUANTA 200F (USA) microscope equipped with energy dispersive X-ray (EDX) spectroscopy.

\subsection{Sensor Fabrication and Gas Sensing Performance Test.} A proper amount of $\mathrm{ZnO}$ materials was mixed with several drops of deionized water to form a paste. The paste was coated on a ceramic tube on which a pair of gold electrodes was previously printed, and then a Ni-Cr heating wire was inserted in the tube to form a gas sensor. The thickness of the sensing films was about $300 \mu \mathrm{m}$. The alumina tube was then welded onto a pedestal to form a final sensor unit. The sensors were aged at $300^{\circ} \mathrm{C}$ for ten days to achieve the stabilization. The gas sensing tests were operated in a static state gas sensing test system [17]. When the resistance of all the sensors was stable, target gas was injected into the test chamber by a microinjector through a rubber plug. After measurement, the sensor was exposed to air by opening the chamber to the atmosphere. The output voltages of the sensors were measured under a bias voltage of $10 \mathrm{~V} \mathrm{DC}$. The sensor response value $(S)$ was defined as $S=R_{a} / R_{g}$, where $R_{a}$ and $R_{g}$ were the resistance of the sensor in air and in target gas, respectively. The time taken by the sensor to achieve $90 \%$ of the total resistance change was defined as the response time in the case of response (target gas adsorption) or the recovery

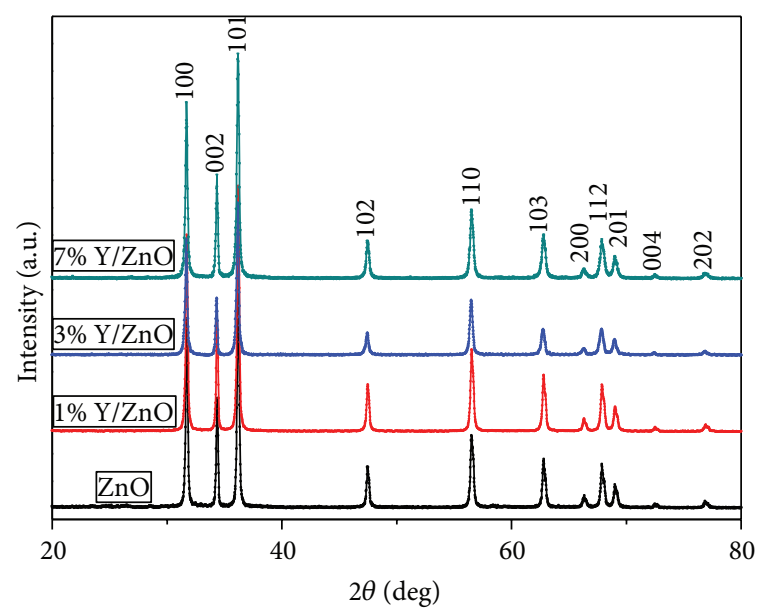

FIGURE 1: XRD patterns of pure, 1 at $\%, 3$ at $\%$, and 7 at $\%$ Y-doped $\mathrm{ZnO}$ nanorods.

time in the case of recovery (target gas desorption). The whole system was controlled by a computer automatically. All the tests were operated under about $30 \%$ relative humidity.

\section{Results and Discussion}

3.1. Characterization Results and Growth Process Analysis of $\mathrm{ZnO}$ Nanorods. Figure 1 shows the XRD patterns of pure, 1 at $\%, 3$ at $\%$, and 7 at $\%$ Y-doped $\mathrm{ZnO}$ nanorods. The samples are polycrystalline in nature and no further heat treatment is required. All the diffraction peaks can be indexed as hexagonal $\mathrm{ZnO}$ with lattice constants $a=0.325 \mathrm{~nm}$ and $c=0.521 \mathrm{~nm}$, which are consistent with the values in the standard card (Joint Committee for Powder Diffraction Studies (JCPDS) card \# 36-1451).

Figure 2 shows the SEM images of the as-prepared nanorods with different $Y$ doping rates: (a) pure, (b) 1 at\%, (c) 3 at $\%$, and (d) 7 at $\%$ Y-doped $\mathrm{ZnO}$ nanorods. The average diameters of pure, 1 at $\%, 3$ at $\%$, and 7 at $\%$ Y-doped $\mathrm{ZnO}$ nanorods are $\sim 300 \mathrm{~nm}, 300 \mathrm{~nm} \sim 1.5 \mu \mathrm{m}, 2 \sim 3 \mu \mathrm{m}$, and $2 \sim$ $3 \mu \mathrm{m}$, respectively. It can be seen that the average diameters of the products are increased as the $\mathrm{Y}$ content increased from zero to 3 at $\%$.

Figure 3 demonstrates the EDX analysis for the 1 at $\%$ Ydoped $\mathrm{ZnO}$ nanorods. We can see that the energy dispersive $\mathrm{X}$-ray spectroscopic analysis confirmed the presence of $\mathrm{Zn}$ and $\mathrm{Y}$ elements in the investigated area from the Y-doped $\mathrm{ZnO}$ nanorods by a hydrothermal process.

The growth process of $\mathrm{ZnO}$ crystallites is generally accepted via the following mechanism [18-20]: HMTA $\left(\mathrm{C}_{6} \mathrm{H}_{12} \mathrm{~N}_{4}\right)$ is extensively used in the synthesis of $\mathrm{ZnO}$ nanostructures, and it provides the ammonia molecules $\left(\mathrm{NH}_{3}\right)$ and the hydroxide ions $\left(\mathrm{OH}^{-}\right)$to the solution (1) and (2). And $\mathrm{Zn}\left(\mathrm{NO}_{3}\right)_{2} \cdot 6 \mathrm{H}_{2} \mathrm{O}$ is apparently used to provide the zinc ions (3). In this experiment, $\mathrm{OH}^{-}$is abundant in the mixed aqueous solution, fresh formed $\mathrm{Zn}(\mathrm{OH})_{2}$ precipitation (4) can be dissolved immediately by reacting with superfluous $\mathrm{OH}^{-}$ions, and then a transparent $\mathrm{Zn}(\mathrm{OH})_{4}{ }^{2-}$ solution is obtained (5). In the hydrothermal process, the $\mathrm{Zn}(\mathrm{OH})_{4}{ }^{2-}$ 


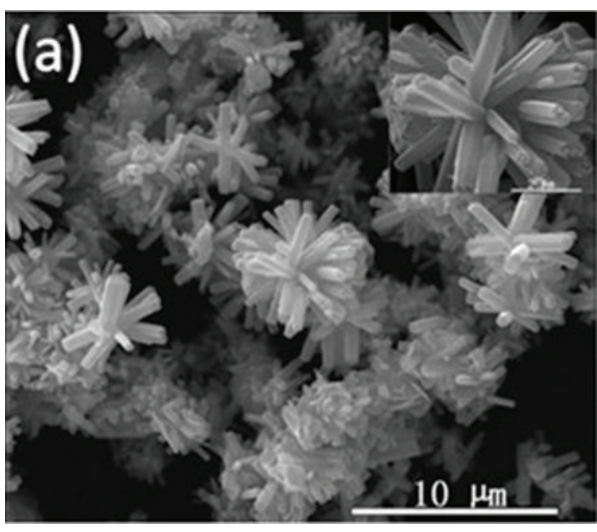

(a)

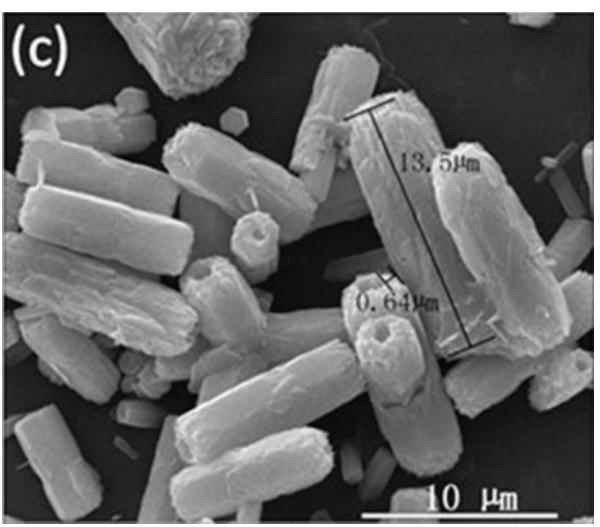

(c)

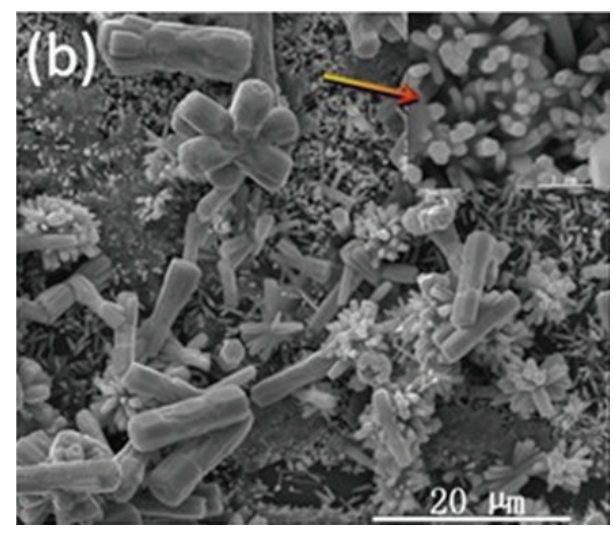

(b)

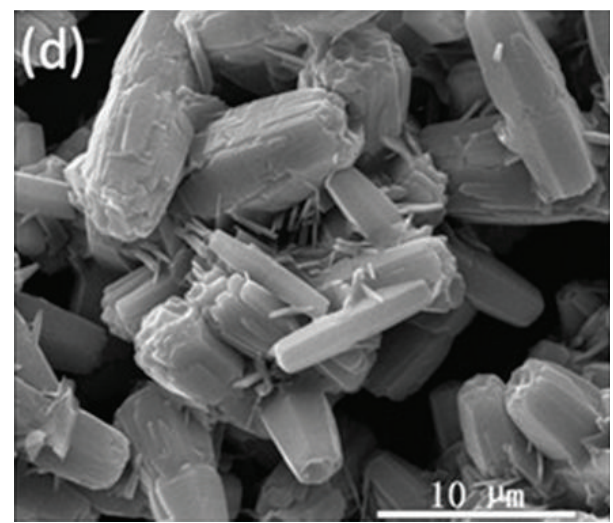

(d)

Figure 2: SEM images of (a) pure, (b) 1 at\%, (c) 3 at\%, and (d) 7 at $\%$ Y-doped $\mathrm{ZnO}$ nanorods.

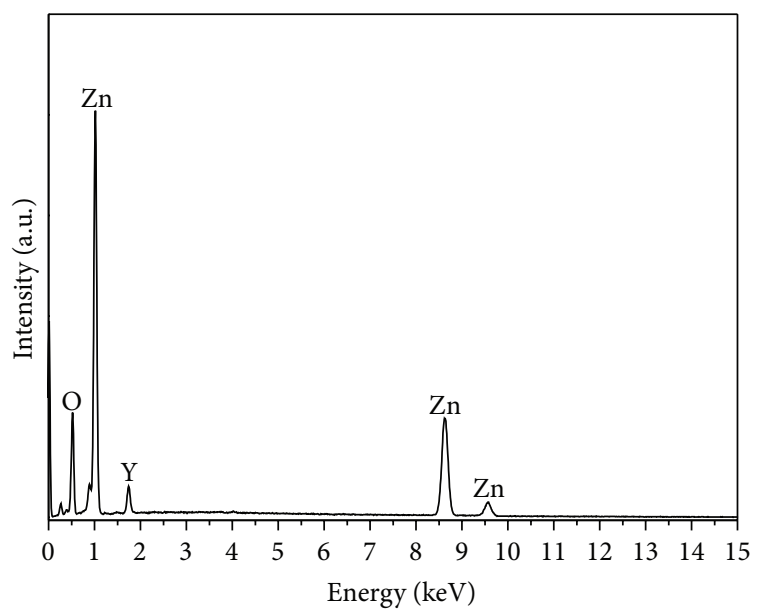

Figure 3: The EDX analysis of the 1 at\% Y-doped $\mathrm{ZnO}$ nanorods.

combines with each other and dehydrates into $\mathrm{ZnO}$ nuclei simultaneously. And then these $\mathrm{ZnO}$ nuclei self-assemble to form the rod-like nanostructures along a preferred axis orientation (6):

$$
\begin{aligned}
\mathrm{C}_{6} \mathrm{H}_{12} \mathrm{~N}_{4}+6 \mathrm{H}_{2} \mathrm{O} & \longleftrightarrow 6 \mathrm{HCHO}+4 \mathrm{NH}_{3} \\
\mathrm{NH}_{3}+\mathrm{H}_{2} \mathrm{O} & \longleftrightarrow \mathrm{NH}_{4}^{+}+\mathrm{OH}^{-}
\end{aligned}
$$

$$
\begin{gathered}
\mathrm{Zn}\left(\mathrm{NO}_{3}\right)_{2} \longrightarrow \mathrm{Zn}^{2+}+2 \mathrm{NO}_{3}{ }^{-} \\
\mathrm{Zn}^{2+}+2 \mathrm{OH}^{-} \longrightarrow \mathrm{Zn}(\mathrm{OH})_{2} \downarrow \\
\mathrm{Zn}(\mathrm{OH})_{2}+2 \mathrm{OH}^{-} \longrightarrow \mathrm{Zn}(\mathrm{OH})_{4}{ }^{2-} \\
\mathrm{Zn}(\mathrm{OH})_{4}{ }^{2-} \longrightarrow \mathrm{ZnO}+\mathrm{H}_{2} \mathrm{O}+2 \mathrm{OH}^{-}
\end{gathered}
$$

3.2. Gas Sensing Properties. Gas sensing properties were performed at different temperatures to find out the optimum operating condition for acetone detection. Figure 4 shows the responses of pure, 1 at $\%, 3$ at\%, and 7 at $\%$ Y-doped $\mathrm{ZnO}$ nanorods gas sensors to $100 \mathrm{ppm}$ acetone vapor at different operating temperatures. The responses of all samples are found to increase with increasing the operating temperature, which attain the maximum at $400^{\circ} \mathrm{C}$, and then decrease with a further rise of the operating temperature. This behavior can be explained from the kinetics and mechanics of gas adsorption and desorption on the surface of $\mathrm{ZnO}$ [21-24]. When the operating temperature is low, the chemical activation of nanorods is small, leading to a very small response. When the temperature is too high, some adsorbed gas molecules may escape before their reaction with the sensing material due to their enhanced activation; thus, the response will decrease correspondingly. At the optimal temperature of 


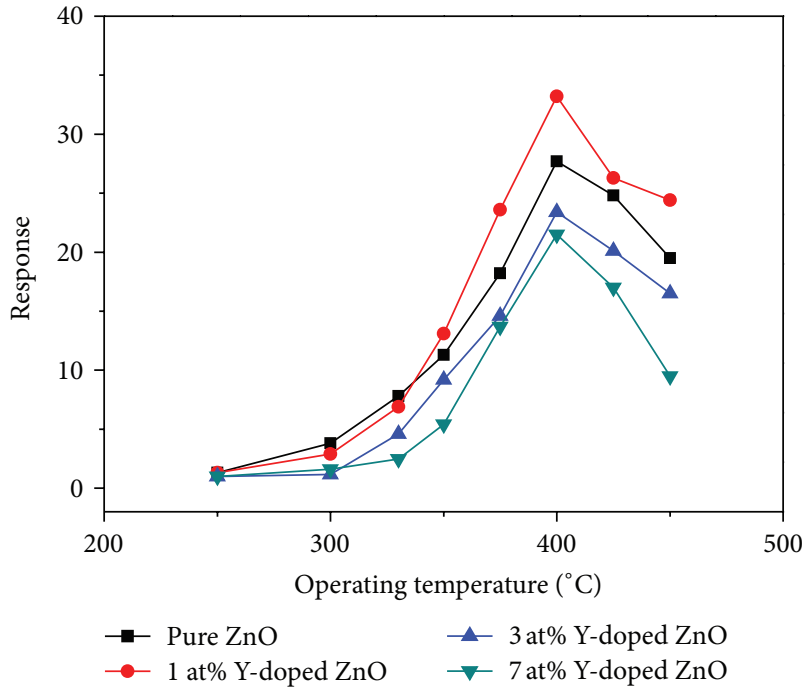

Figure 4: Responses of pure, 1 at $\%, 3$ at $\%$, and 7 at $\%$ Y-doped $\mathrm{ZnO}$ nanorods to $100 \mathrm{ppm}$ acetone at different temperatures.

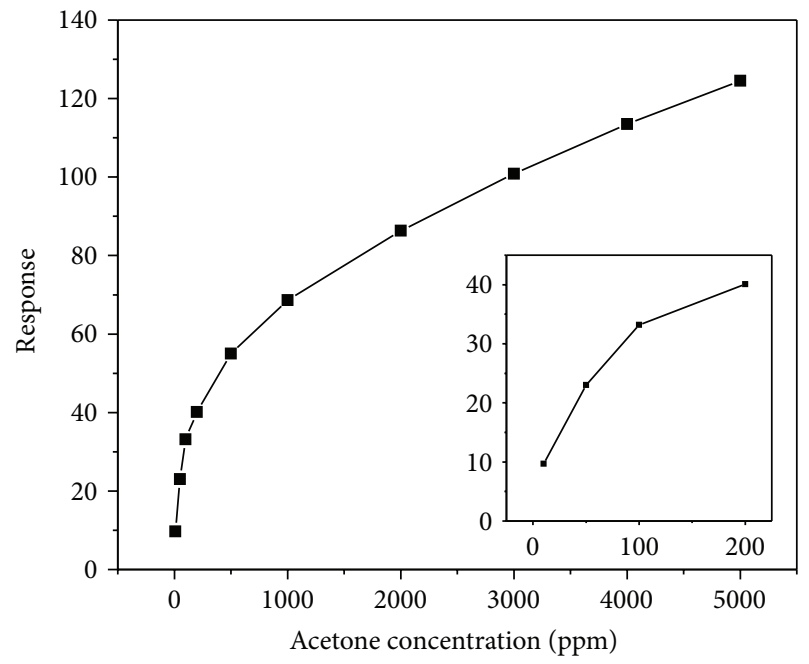

Figure 5: Responses of 1 at\% Y-doped $\mathrm{ZnO}$ nanorods to different concentrations of acetone at $400^{\circ} \mathrm{C}$; the insert shows the calibration curve in low concentration range.

$400^{\circ} \mathrm{C}$ (corresponding to the maximum response), 1 at $\% \mathrm{Y}-$ doped $\mathrm{ZnO}$ nanorods exhibit the highest response values. Thus, 1 at $\%$ Y-doped $\mathrm{ZnO}$ nanorods were applied in the entire investigations hereafter.

Figure 5 shows the sensor response versus acetone concentration at operating temperature $400^{\circ} \mathrm{C}$, and the insert shows the calibration curve in low concentration range. We can see that the sensitivity (the slop of the curve) of the sensor is higher in low acetone concentration range than in high concentration range. The lowest concentration of the acetone that the sensor can detect is $10 \mathrm{ppm}$ with the response value of 4.3 .

The transient properties of 1 at\% Y-doped $\mathrm{ZnO}$ nanorods sensor to different concentrations of acetone are shown in Figure 6. For acetone vapor at concentration levels of 100 ,

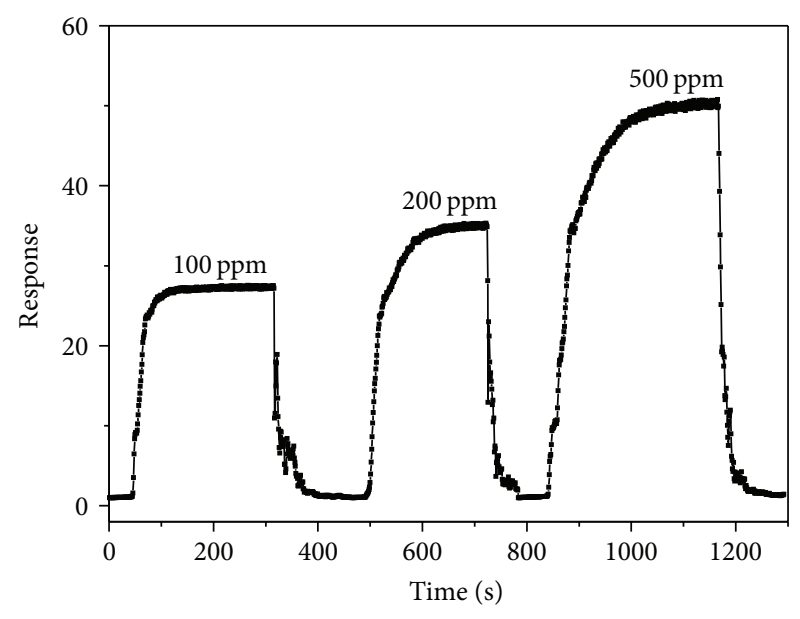

Figure 6: The transient property of 1 at\% Y-doped $\mathrm{ZnO}$ nanorods sensor to 100,200 , and $500 \mathrm{ppm}$ acetone consecutively.

200 , and $500 \mathrm{ppm}$, the responses are about 33.2, 40.1, and 55 , respectively. The response times are about $30 \mathrm{~s}, 34 \mathrm{~s}$, and $42 \mathrm{~s}$ for $100 \mathrm{ppm}, 200 \mathrm{ppm}$, and $500 \mathrm{ppm}$ acetone, respectivily. Correspondingly, the recovery times are about $90 \mathrm{~s}$, $100 \mathrm{~s}$, and $115 \mathrm{~s}$, respectively. As the concentration increases, the response time and the recovery time are both slightly increased. The sensor selectivity was tested by exposing it to $100 \mathrm{ppm}$ different gases at operating temperature $400^{\circ} \mathrm{C}$, as shown in Figure 7. We can see from Figure 7 that the sensor response to acetone $\left(\mathrm{CH}_{3} \mathrm{COCH}_{3}\right)$ is higher than to ammonia $\left(\mathrm{NH}_{3}\right)$, benzene $\left(\mathrm{C}_{6} \mathrm{H}_{6}\right)$, formaldehyde $(\mathrm{HCHO})$, toluene $\left(\mathrm{C}_{6} \mathrm{H}_{5} \mathrm{CH}_{3}\right)$, and methanol $\left(\mathrm{CH}_{3} \mathrm{OH}\right)$.

3.3. Gas Sensing Mechanism. For most semiconducting oxide gas sensor, the change in resistance is primarily caused by the adsorption and desorption of gas molecules on the surface of the sensing films $[25,26]$. As a typical $n$-type MOS sensor, the $\mathrm{ZnO}$ based sensor belongs to the surfacecontrolled type [27]; namely, the sensor response is attributed to the chemisorptions of oxygen on the oxide surface and the subsequent reaction between adsorbed oxygen and tested gas, which brings the resistance of the sensing material change. In ambient air, $\mathrm{ZnO}$ nanorods adsorb the oxygen molecule on the surface. The adsorbed oxygen is changed to various chemical adsorptive states $\left(\mathrm{O}_{2}^{-}, \mathrm{O}^{2-}\right.$, and $\left.\mathrm{O}^{-}\right)$by capturing electrons from the conductance band:

$$
\begin{gathered}
\mathrm{O}_{2(\mathrm{~g})} \Longleftrightarrow \mathrm{O}_{2(\mathrm{ads})} \\
\mathrm{O}_{2(\mathrm{ads})}+\mathrm{e}^{-} \longrightarrow \mathrm{O}_{2(\mathrm{ads})}^{-} \\
\mathrm{O}_{2(\mathrm{ads})}{ }^{-}+\mathrm{e}^{-} \longrightarrow 2 \mathrm{O}_{(\mathrm{ads})}^{-} \\
\mathrm{O}_{(\mathrm{ads})}^{-}+\mathrm{e}^{-} \longrightarrow \mathrm{O}_{(\text {ads })}^{2-}
\end{gathered}
$$

Consequently, $\mathrm{ZnO}$ will show high resistance. According to the report by Takata et al. [28], the stable oxygen ions are $\mathrm{O}_{2}{ }^{-}$below $100^{\circ} \mathrm{C}, \mathrm{O}^{-}$between 100 and $300^{\circ} \mathrm{C}$, and $\mathrm{O}^{2-}$ above $300^{\circ} \mathrm{C}$. The operating temperature of the 1 at $\%$ Y-doped $\mathrm{ZnO}$ 


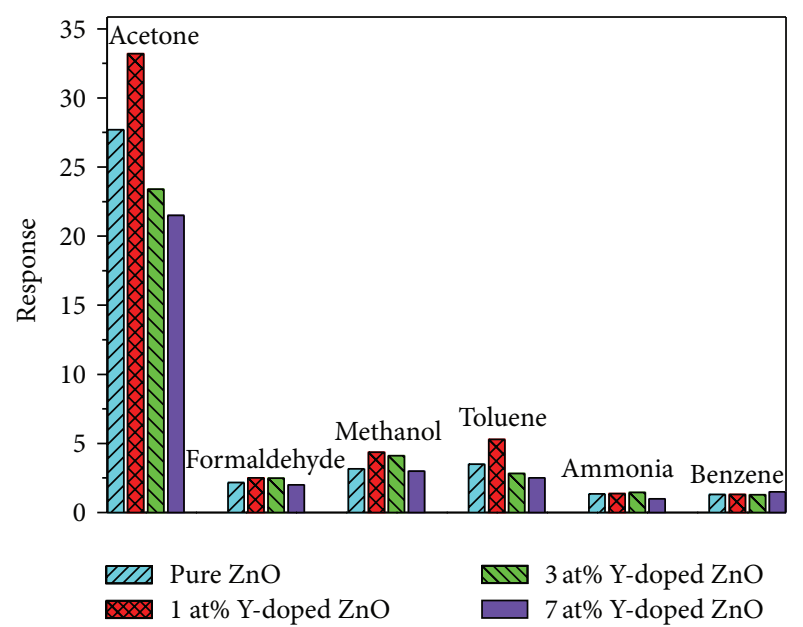

FIgURE 7: Responses of pure, 1 at $\%, 3$ at $\%$, and 7 at $\%$ Y-doped $\mathrm{ZnO}$ nanorods sensors to $100 \mathrm{ppm}$ different gases.

nanorods sensor is $400^{\circ} \mathrm{C}$, so $\mathrm{O}^{2-}$ is believed to be dominant state for adsorbed oxygen.

When $\mathrm{ZnO}$ is exposed to reductive gas acetone $\left(\mathrm{CH}_{3} \mathrm{COCH}_{3}\right)$, the acetone molecules will react with adsorbed $\mathrm{O}^{2-}$ species on the $\mathrm{ZnO}$ surface to form $\mathrm{CO}_{2}$ and $\mathrm{H}_{2} \mathrm{O}$, which leads to the increase of carrier concentration and the decrease of the electrical resistance:

$$
\mathrm{CH}_{3} \mathrm{COCH}_{3(\mathrm{~g})}+\mathrm{O}_{\mathrm{ads}}^{2-} \longrightarrow \mathrm{CO}_{2(\mathrm{~g})}+\mathrm{H}_{2} \mathrm{O}_{(\mathrm{g})}+2 \mathrm{e}^{-}
$$

As a catalyst, $\mathrm{Y}$ not only enhances the activity of the semiconductor surface, but also promotes the electrons transfer from the reducing gas (acetone vapor) to $\mathrm{ZnO}[8,29]$. On the other hand, impurity energy levels introduced by doping reduced the barrier height of $\mathrm{ZnO}$ [30]. When Y-doped $\mathrm{ZnO}$ nanorods are exposed to acetone vapor, its barrier height will become lower and depletion layer will be thinner, resulting in big changes of the resistance of the sensitive material. Therefore, the response of the Y-doped $\mathrm{ZnO}$ nanorods to acetone vapor increases. However, the samples with excess $\mathrm{Y}$ doping such as 7 at\% deteriorate with worse response to acetone vapor (as shown in Figure 7). The mechanism of the gas response of $\mathrm{ZnO}$ doped with different concentration of $\mathrm{Y}$ also needs further investigation.

\section{Conclusion}

In summary, pure and $\mathrm{Y}$-doped $\mathrm{ZnO}$ nanorods are synthesized via hydrothermal method. Gas sensing measurement reveals that $\mathrm{Y}$ doping can enhance the acetone sensing properties of $\mathrm{ZnO}$ nanorods, and the optimal doping concentration was 1 at $\%$. The acetone vapor concentration ranges from $10 \mathrm{ppm}$ to $5000 \mathrm{ppm}$. The response and recovery times of 1 at $\%$ Y-doped $\mathrm{ZnO}$ nanorods to $100 \mathrm{ppm}$ acetone are about $30 \mathrm{~s}$ and $90 \mathrm{~s}$, respectively. The sensor got good selectivity of acetone to ammonia, benzene, formaldehyde, toluene, and methanol. Doping yttrium into $\mathrm{ZnO}$ enhances the activity of the semiconductor surface and introduces impurity energy levels that reduce the barrier height of $\mathrm{ZnO}$.

\section{Acknowledgment}

This paper was supported by the National Natural Science Foundation of China $(61176068,61131004$, and 61001054).

\section{References}

[1] M. H. Huang, S. Mao, H. Feick et al., "Room-temperature ultraviolet nanowire nanolasers," Science, vol. 292, no. 5523, pp. 1897-1899, 2001.

[2] S.-H. Choi, G. Ankonina, D.-Y. Youn et al., "Hollow $\mathrm{ZnO}$ nanofibers fabricated using electrospun polymer templates and their electronic transport properties," ACS Nano, vol. 3, no. 9, pp. 2623-2631, 2009.

[3] Z. Yuan, X. Jiaqiang, X. Qun, L. Hui, P. Qingyi, and X. Pengcheng, "Brush-like hierarchical zno nanostructures: synthesis, photoluminescence and gas sensor properties," Journal of Physical Chemistry C, vol. 113, no. 9, pp. 3430-3435, 2009.

[4] A. K. Bai, A. Singh, and R. K. Bedi, "Characterization and ammonia sensing properties of pure and modified $\mathrm{ZnO}$ films," Applied Physics A, vol. 103, no. 2, pp. 497-503, 2011.

[5] S. K. Youn, N. Ramgir, C. Wang, K. Subannajui, V. Cimalla, and M. Zacharias, "Catalyst-free growth of $\mathrm{ZnO}$ nanowires based on topographical confinement and preferential chemisorption and their use for room temperature CO detection," Journal of Physical Chemistry C, vol. 114, no. 22, pp. 10092-10100, 2010.

[6] X. Niu, W. Du, and W. Du, "Preparation and gas sensing properties of ZnM2O4 (M = Fe, Co, Cr)," Sensors and Actuators $B$, vol. 99, no. 2-3, pp. 405-409, 2004.

[7] X.-J. Wang, W. Wang, and Y.-L. Liu, "Enhanced acetone sensing performance of $\mathrm{Au}$ nanoparticles functionalized flower-like ZnO," Sensors and Actuators B, vol. 168, pp. 39-45, 2012.

[8] L. Liu, S. Li, J. Zhuang et al., "Improved selective acetone sensing properties of Co-doped $\mathrm{ZnO}$ nanofibers by electrospinning," Sensors and Actuators B, vol. 155, no. 2, pp. 782-788, 2011.

[9] S. Wei, Y. Yu, and M. Zhou, "CO gas sensing of Pd-doped ZnO nanofibers synthesized by electrospinning method," Materials Letters, vol. 64, no. 21, pp. 2284-2286, 2010.

[10] T. Jia, W. Wang, F. Long, Z. Fu, H. Wang, and Q. Zhang, "Synthesis, characterization and luminescence properties of Ydoped and Tb-doped $\mathrm{ZnO}$ nanocrystals," Materials Science and Engineering B, vol. 162, no. 3, pp. 179-184, 2009.

[11] R. Kaur, A. V. Singh, K. Sehrawat, N. C. Mehra, and R. M. Mehra, "Sol-gel derived yttrium doped $\mathrm{ZnO}$ nanostructures," Journal of Non-Crystalline Solids, vol. 352, pp. 2565-2568, 2006.

[12] Y. Natsume, H. Sakata, T. Hirayama, and H. Yanagida, "Lowtemperature conductivity of $\mathrm{ZnO}$ films prepared by chemical vapor deposition," Journal of Applied Physics, vol. 72, no. 9, pp. 4203-4207, 1992.

[13] J. P. Xu, S. B. Shi, X. S. Zhang, Y. W. Wang, M. X. Zhu, and L. $\mathrm{Li}$, "Structural and optical properties of (Al, K)-co-doped $\mathrm{ZnO}$ thin films deposited by a sol-gel technique," Materials Science in Semiconductor Processing, vol. 16, no. 3, pp. 732-737, 2013.

[14] J. Aranovich, A. Ortiz, and R. H. Bube, "Optical and electrical properties of $\mathrm{ZnO}$ films prepared by spray pyrolysis for solar cell applications," Journal of Vacuum Science \& Technology, vol. 16, no. 4, pp. 994-1003, 1979.

[15] X. R. Ye, D. Z. Jia, J. Q. Yu, X. Q. Xin, and Z. L. Xue, "Fabrication and characterization of carbon nanotube/poly(vinyl alcohol) composites," Advanced Materials, vol. 11, no. 11, pp. 937-941, 1999. 
[16] S. K. Mishra, R. K. Srivastava, S. G. Prakash, R. S. Yadav, and A. C. Pandey, "Direct acceleration of an electron in infinite vacuum by a pulsed radially-polarized laser beam," Opto-Electronics Review, vol. 18, no. 4, pp. 467-473, 2010.

[17] P. J. Yao, J. Wang, W. L. Chu, and Y. W. Hao, "Preparation and characterization of $\mathrm{La}_{1-x} \mathrm{Sr}_{x} \mathrm{FeO}_{3}$ materials and their formaldehyde gas-sensing properties," Journal of Materials Science, vol. 48, no. 1, pp. 441-450, 2013.

[18] J. Huang, Y. Wu, C. Gu et al., "Large-scale synthesis of flowerlike $\mathrm{ZnO}$ nanostructure by a simple chemical solution route and its gas-sensing property," Sensors and Actuators B, vol. 146, no. 1, pp. 206-212, 2010.

[19] L. L. Yang, Q. X. Zhao, and M. Willander, "Size-controlled growth of well-aligned $\mathrm{ZnO}$ nanorod arrays with two-step chemical bath deposition method," Journal of Alloys and Compounds, vol. 469, no. 1-2, pp. 623-629, 2009.

[20] L. Yang, D. Qiu, F. Yu, S. Chen, and Y. Yin, “3D flowerlike ZnO micro-nanostructures via site-specific second nucleation in the zincethylenediaminehexamethylenetetramine tertiary system," Materials Science in Semiconductor Processing, vol. 14, no. 3-4, pp. 193-198, 2011.

[21] N. Yamazoe, J. Fuchigami, M. Kishikawa, and T. Seiyama, "Interactions of tin oxide surface with $\mathrm{O}_{2}, \mathrm{H}_{2} \mathrm{O}$ And $\mathrm{H}_{2}$," Surface Science, vol. 86, pp. 335-344, 1979.

[22] J. Herrán, O. Fernández-González, I. Castro-Hurtado, T. Romero, G. G Mandayo, and E. Castaño, "Photoactivated solid-state gas sensor for carbon dioxide detection at room temperature," Sensors and Actuators B, vol. 149, no. 2, pp. 368372, 2010.

[23] M. Ghasdi and H. Alamdari, "CO sensitive nanocrystalline $\mathrm{LaCoO}_{3}$ perovskite sensor prepared by high energy ball milling," Sensors and Actuators B, vol. 148, no. 2, pp. 478-485, 2010.

[24] G. Sakai, N. Matsunaga, K. Shimanoe, and N. Yamazoe, "Theory of gas-diffusion controlled sensitivity for thin film semiconductor gas sensor," Sensors and Actuators B, vol. 80, no. 2, pp. 125131, 2001.

[25] Q. Wan, Q. H. Li, Y. J. Chen et al., "Fabrication and ethanol sensing characteristics of $\mathrm{ZnO}$ nanowire gas sensors," Applied Physics Letters, vol. 84, no. 18, pp. 3654-3656, 2004.

[26] Y. Shimizu, S. Kai, Y. Takao, T. Hyodo, and M. Egashira, "Correlation between methylmercaptan gas-sensing properties and its surface chemistry of $\mathrm{SnO}_{2}$-based sensor materials," Sensors and Actuators B, vol. 65, no. 1, pp. 349-357, 2000.

[27] C. Peng and Y. L. Liu, "Enhanced acetone sensing characteristics by decorating nanoparticles on $\mathrm{ZnO}$ flower-like structures," Applied Physics A, vol. 111, no. 4, pp. 1151-1157, 2013.

[28] M. Takata, D. Tsubone, and H. Yanagida, "Dependence of electrical conductivity of $\mathrm{ZnO}$ on degree of sintering," Journal of the American Ceramic Society, vol. 59, no. 1-2, pp. 4-8, 1976.

[29] M. E. Franke, T. J. Koplin, and U. Simon, "Metal and metal oxide nanoparticles in chemiresistors: does the nanoscale matter?" Small, vol. 2, pp. 36-50, 2006.

[30] X. C. Wang, M. G. Zhao, F. Liu, J. F. Jia, X. J. Li, and L. L. Gao, " $\mathrm{C}_{2} \mathrm{H}_{2}$ gas sensor based on Ni-doped $\mathrm{ZnO}$ electrospun nanofibers," Ceramics International, vol. 39, no. 3, pp. 28832887, 2013. 

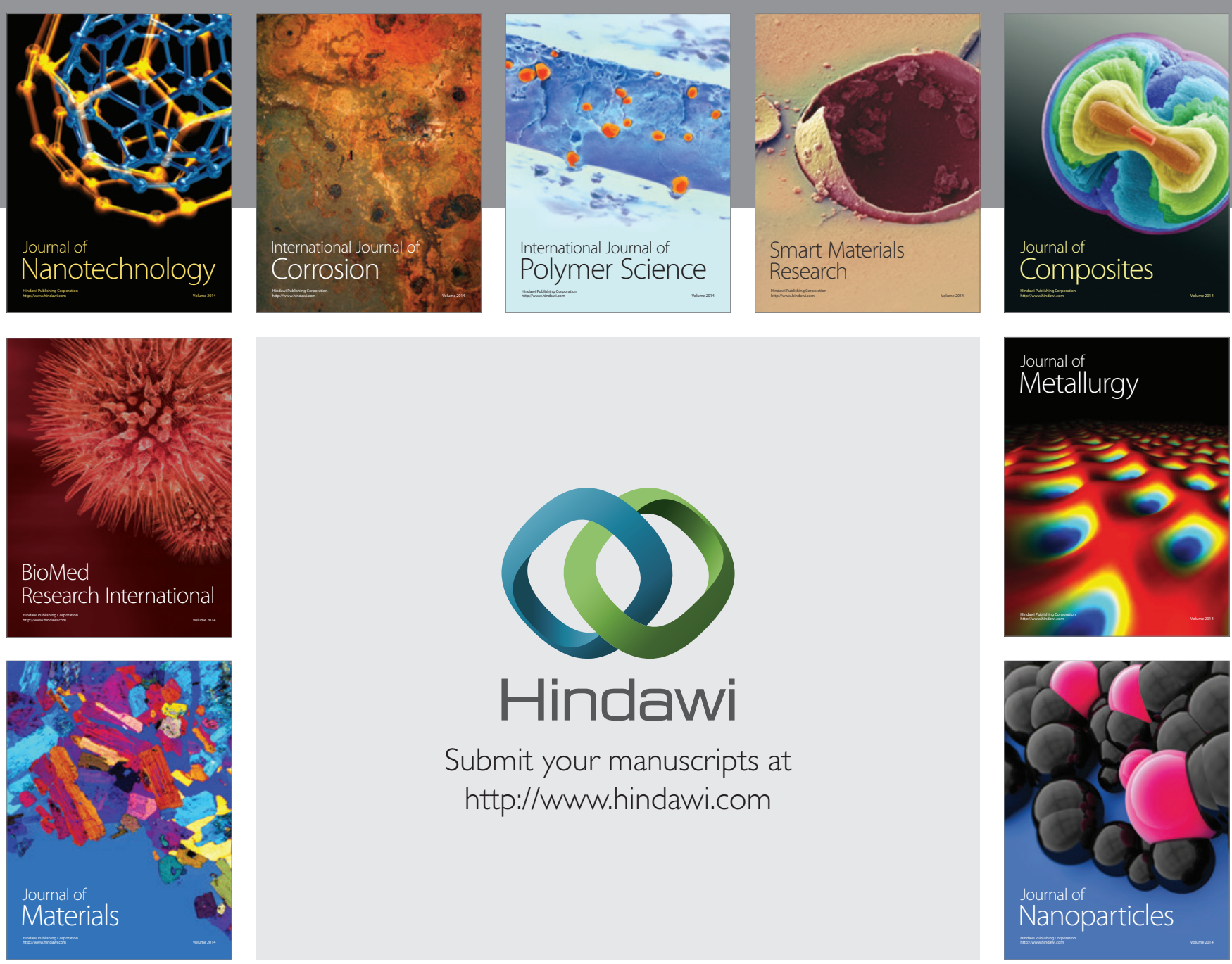

Submit your manuscripts at http://www.hindawi.com
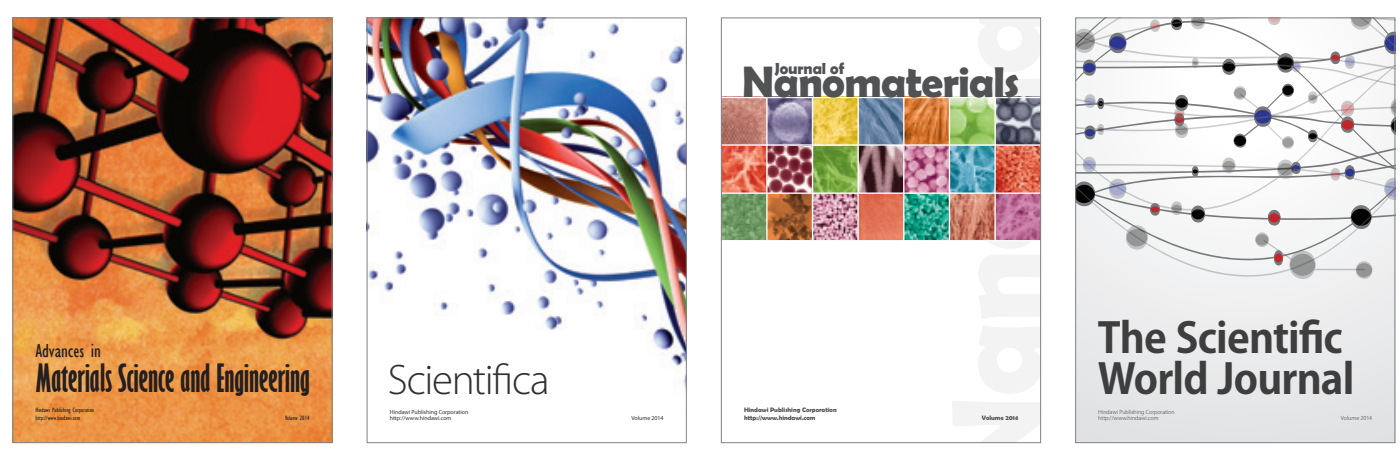

\section{The Scientific World Journal}
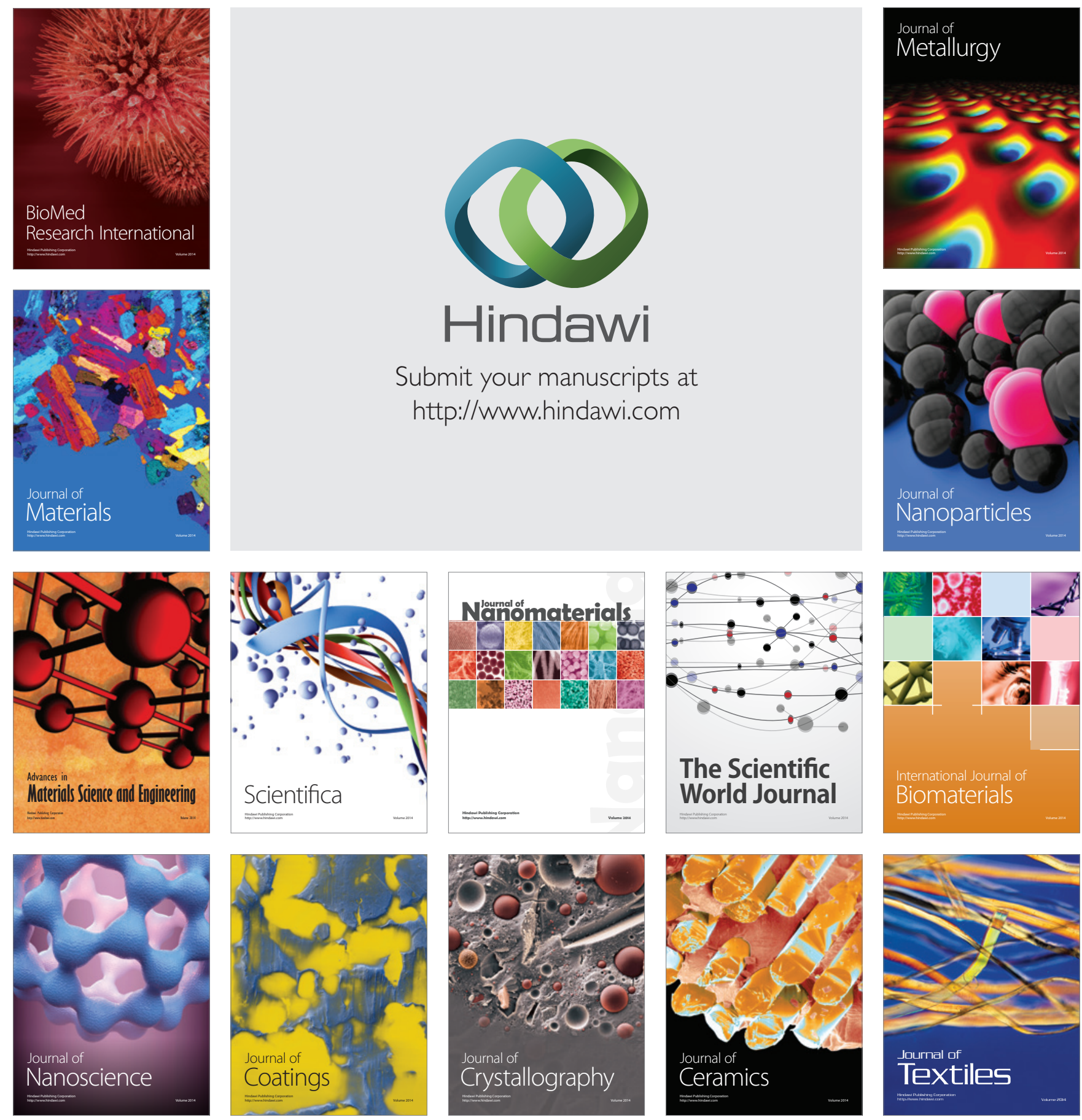